\title{
Geophysical characterization and hydraulic properties of unconsolidated floodplain aquifer system in Wamako area, Sokoto State, north-western Nigeria
}

\author{
O. A. Akinbiyi ${ }^{1} \cdot$ M. A. Oladunjoye ${ }^{2} \cdot 0$. A. Sanuade $^{3}\left[0\right.$. Oyedeji $^{4}$
}

Received: 24 November 2018 / Accepted: 2 October 2019 / Published online: 14 October 2019

(c) The Author(s) 2019

\begin{abstract}
The subsurface internal geometry of Rima River floodplain located in north-western area of Nigeria was investigated using 2D resistivity imaging, vertical electrical sounding (VES) and laboratory analyses. Four profiles were acquired using Wenner array. The apparent resistivity computed was used to produce $2 \mathrm{D}$ electrical resistivity pseudosections using RES2DINV software. A total of nine VESs were acquired along the four profiles in the study area with $A B / 2$ of 1 to $100 \mathrm{~m}$. Quantitative interpretation of VES curves was done by partial curve matching and computer-assisted 1D forward modelling with the WinResist version 1.0 software. Five pits were dug along the profiles to confirm the interpreted results from the geophysical surveys. Soil samples were collected from the pits at various depths, and hydraulic conductivity $(K)$ was estimated in the laboratory using the constant head permeability test following standard procedure. Interpretations of electrical resistivity technique show three to four subsurface layers including topsoil, sandy material and clay/saturated clayey materials. The sandy material is believed to be saturated with water with appreciable amount of porosity and permeability. This layer was further confirmed by pitting around the study area. From the laboratory and empirical estimation of $K$, it was discovered that the $K$ value ranges from $10^{-2}$ to $10^{-6} \mathrm{~m} / \mathrm{s}$, which shows that the sample is clean sand which is moderately to highly permeable. The grain size analysis revealed from the cumulative plot that the sample falls predominantly within medium-sized sand, which makes the study area a good aquifer system.
\end{abstract}

Keywords Floodplain $\cdot$ Electrical resistivity $\cdot$ Aquifer $\cdot$ Hydraulic conductivity $\cdot$ Permeability

\section{Introduction}

The mapping of lithology and geometry of sand and gravel, channels and valley fills is very important. This is because they are economically significance in that they can serve as reservoirs in both groundwater and hydrocarbon exploration. They can also serve as sources of placer

O. A. Sanuade

sheunsky@gmail.com

1 Department of Geological Technology, Federal Polytechnic, Ede, Ede, Osun State, Nigeria

2 Department of Geology, University of Ibadan, Ibadan, Nigeria

3 Geosciences Department, King Fahd University of Petroleum and Minerals, Dhahran, Saudi Arabia

4 Geoscience Research Institute, Nigerian Geological Survey Agency, Abuja, Nigeria deposits (gold, tin and diamonds) that are of economic importance. Furthermore, floodplains are very essential for agricultural practice in the north-western part of Nigeria in that they are irrigation potentials and could serve as a major source of groundwater for domestic consumption and livestock grazing. The decline in the amount of rainfall in the semiarid northern Nigeria due to climate change has made floodplains in these zones to be under pressure from several sources (Anyadike 1983; Hess et al. 1995). Ette et al. (2017) stated that groundwater is very essential in Sokoto basin due to the decline in the amount of rainfall that falls for few months in the basin area. Also, the sources of surface water in the area usually become unproductive at the peak of dry season. Therefore, farmers and the inhabitants of the lowland areas need to shift their attention to floodplain shallow groundwater resources which have been used for irrigation and domestic uses since 1980s (Hamidu et al. 2017). Therefore, the objectives of this study are to determine the lithology of the 
subsurface layers, the aquifer characteristics and properties of a floodplain, to correlate the geoelectric parameter and hydrologic properties and to characterize the hydrogeology setting of the area with the view to delineating the potential areas for exploiting groundwater.

The above-stated objectives could be achieved by either borehole geophysical techniques or surface geophysical techniques such as ground penetrating radar (GPR), electrical resistivity and seismic method. However, surface electrical resistivity method has proven to be an effective method for mapping the subsurface based on the varying magnitudes of the flow of electric current (Revil et al. 2012; Loke et al. 2013; Adabanija and Oladunjoye 2014; Stan and Stan-Kleczek 2014; Sanuade et al. 2017; Adeeko and Samson 2018; Olaseeni et al. 2018; Olaojo et al. 2018; Oyeyemi et al. 2018). The method is nondestructive, very sensitive and less expensive than other geophysical techniques such as seismic and GPR (Mostafa and Radwan 2017; Riwayat et al. 2018). It offers a very attractive tool for describing the subsurface properties without digging. Moreover, in order to understand the condition of groundwater flow and the movement of dissolved substance in the aquifer, reliable information on the magnitude of the hydraulic conductivity $(K)$ of the aquifer system is required (Altunkaynak 2007). Several laboratory and field methods can be used for characterization of hydraulic properties of aquifer unit (Hogan et al. 2006; Das et al. 2010; Sobotkova et al. 2011; Alagna et al. 2015). There has been advancement in the field scale method of measurements and evaluation of hydraulic properties in different aquifer settings (Bouwer 1989; Butler and Zhan 2004; Fallico 2014; Siltecho et al. 2015).

The study area is located within the floodplain along Rima River in Wamako local government area of Sokoto State, north-western Nigeria (Fig. 1). The area covers approximately $30,000 \mathrm{~m}^{2}$ and is located within latitude $\mathrm{N} 13^{\circ} 06^{\prime} 58^{\prime \prime}$ and $13^{\circ} 07^{\prime} 24^{\prime \prime}$ and longitude $5^{\circ} 15^{\prime} 03^{\prime \prime}$ and $5^{\circ} 15^{\prime} 38^{\prime \prime}$. The terrain in the study area is gently undulating and relatively flat with general absence of major rock exposures. The drainage pattern within the area is subdendritic, made up of dry river and stream channels. The study area falls within a semiarid type of climate condition, that is, the Sahel climate zone with average precipitation between 250 and $500 \mathrm{~mm}$. The raining season extends from mid-May to September while the dry season lasts for more than 7 months starting in November all through until April of the following year. During the dry season, the temperature is high in the day but drops considerably in the night hours due to high rate of transpiration during the day and cloudless sky which forms all night. The vegetation belt of the area falls within the Sahel savannah which is characterized by almost continuous short grasses, shrubs and sparse tree covers.

\section{Geology of the study area}

The study area falls within the Sokoto basin. The basin covers about $10 \%$ in total area of the Lullemeden Basin. Sedimentation in the Sokoto basin occurred in three phases (Kogbe 1979; Bassey and Eminue 2014). The sediment of the first phase directly overlies the basement rocks. This basal sequence of the Sokoto basin belongs to Gundumi and Illo Formations and has been assigned as Pre-Maastrichtian deposits (Kogbe 1979). The second phase has been divided by two cyclothems Maastrichtian and Palaeocene age, respectively. The cyclothems were attributed to the beginning of the Maastrichtian transgression (Kogbe 1979). The sea moved northward from the gulf of Guinea through the Mid-Niger Basin, and the Tethyan Sea moved southward from the north. During this period, Taloka, Dukamaje and Wurno were deposited unconformably on the continental sequence. The presence of the Maastrichtian and Palaeocene unconformity was indicative of break in sedimentation between the Maastrichtian and Palaeocene (Kogbe 1979). The Palaeocene cyclothems took place in the Palaeocene during which Sokoto Group (Dange, Kalambaina and Gamba Formations) were deposited. The third phase started with the gradual withdrawal of the sea at the end of the Palaeocene and a subsequent laying down of the continental Gwandu Formation in the Eocene (Kogbe 1979). All these sediments dip gently and thicken gradually toward the northwest. The stratigraphy of the Sokoto basin is shown in Fig. 2.

The Gundumi Formation is a fluvio-lacustrine deposit having conglomerate as the contact with the basement. Its lithologies are mostly pseudobedded massive feldspathic clayey grits, pebbly sand and conglomerates. Illo Formation is about $240 \mathrm{~m}$ thick, and it is considered a lateral equivalent of the Gundumi Formation. The formation is mostly made up of cross-bedded grits with intercalations of pisolitic and nodular clay. It consists essentially of nonmarine sediment. The lithologies in Taloka Formation include the basal reddish brown siltstone, the shaly siltstone, whitish grey alternating with purple siltstone, white grey siltstone alternating with the brown siltstone and grey clayey siltstone. Its thickness is estimated to be about $6 \mathrm{~m}$. It is Maastrichtian and brackish with brief marine intercalation. It is lying conformably on the Illo Formation. Dukamaje Formation consists predominantly of shales (grey) interbedded with gypsum with some limestone and mudstone. The shale contains numerous fragments of vertebrae and limb bones. The base of the Dukamaje Formation is distinctively marked by a bone bed which is very richly fossiliferous. Wurno Formation consists of sediments made of pale-coloured, friable and fine-grained sandstones, siltstones and intercalated mudstones. The sedimentary structures include bioturbation, 


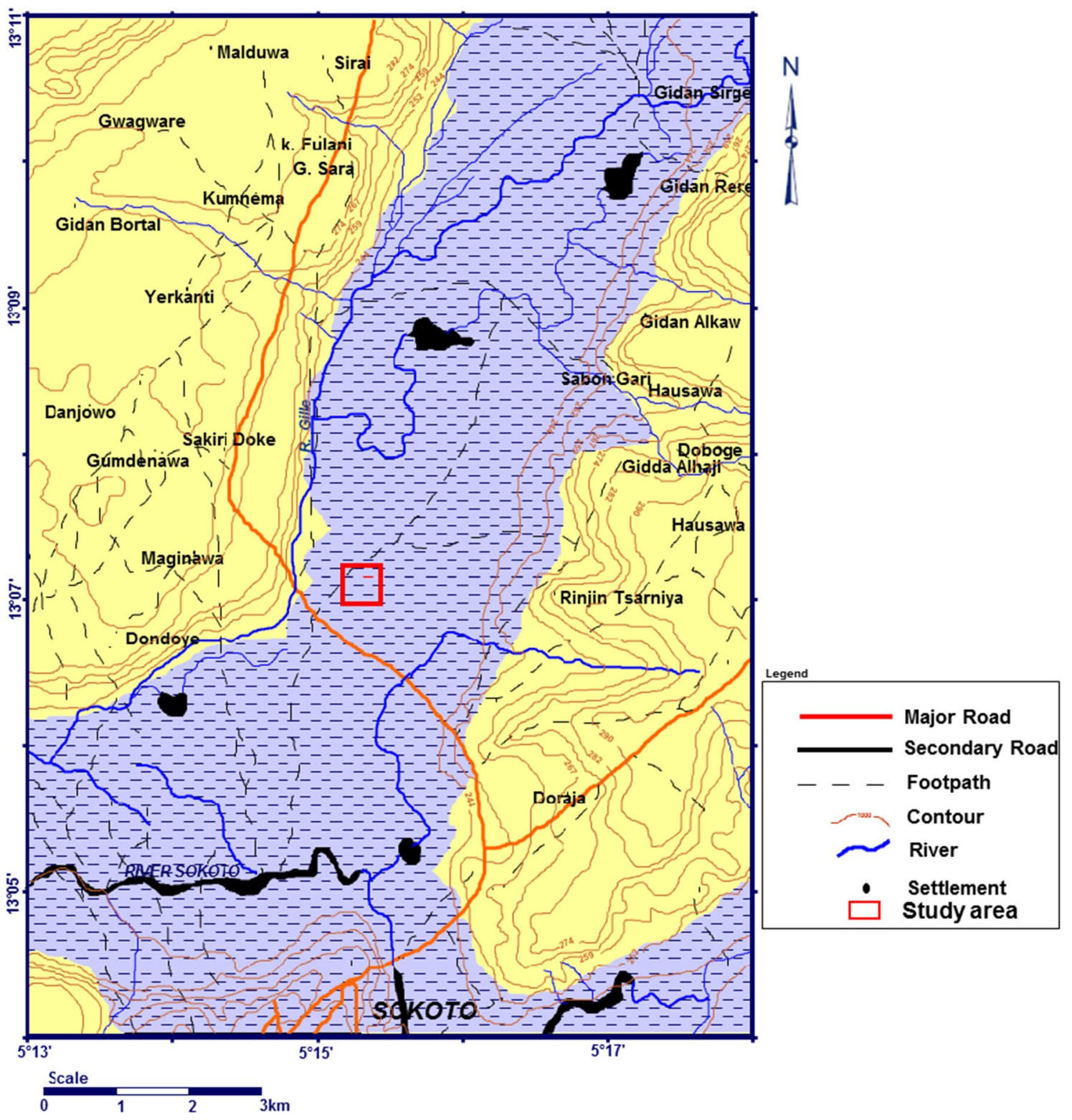

Fig. 1 Topographical map of part of Sokoto showing the study area (NGSA 2004)

flaser bedding (also characteristic of the Taloka Formation). Dange Formation consists of slightly indurated bluish grey shales interbedded with thin layers of yellowish brown limestone. The shale includes bands of gypsum with irregularshaped phosphatic nodules. The nodules are marked with irregular striations and tend to have a dirty white colour but internally they are bluish grey. Kalambaina Formation is in conformable contact with the underlying Dange Formation. It consists of a white marine, clayey limestone and shale (Reyment 1965; Kogbe 1976). Due to the dissolution of limestone, the subsurface thickness of this formation is quite hard to ascertain because it varies, but a maximum thickness recorded from the borehole is over $20 \mathrm{~m}$. Gamba Formation overlies the calcareous Kalambaina Formation which is the grey laminated shale of the Gamba Formation. The shales of the Gamba Formation appear to be folded resulting from the dissolution of the Kalambaina limestone which overlies it directly. Gwandu Formation is made up of thick series of deposits consisting predominantly of red and mottled massive clays with sandstone intercalations. Outcrops of the Gwandu Formation cover about $21,739 \mathrm{~km}^{2}$ in north-western Nigeria. It contains a number of prominent ridges and groups of flat-topped, steep-sided hills capped by ironstones. Rock exposures are rare on the plain, but numerous on the hillsides where they are usually small and obscured by rain wash and ironstones. 


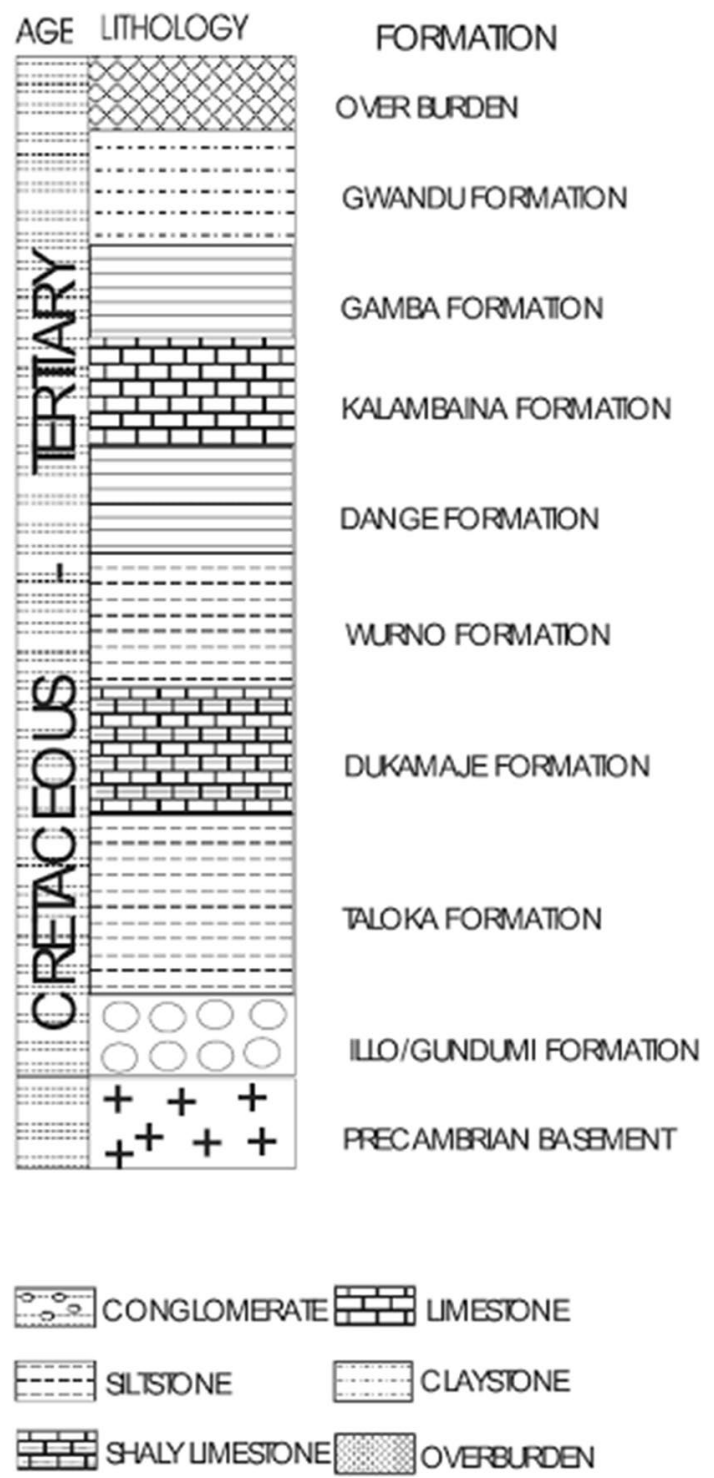

Fig. 2 Generalized chronostratigraphic column for Sokoto Basin, north-western Nigeria (Adelana et al. 2002)

\section{Methodology}

\section{Geophysical survey}

A geophysical survey involving the electrical resistivity method was carried out in the study area using Schlumberger and Wenner electrode arrays. Four profiles were acquired using Wenner array with two along west-east azimuth and two oriented along north-south azimuth (Fig. 3). The computed apparent resistivity values were used to construct $2 \mathrm{D}$ electrical resistivity pseudosection using RES2DINV software by Loke (2000). Vertical electrical sounding (VES) was carried out along all the four traverses. A total of nine VESs were acquired in the study area with $A B / 2$ of 1 to
$100 \mathrm{~m}$. The apparent resistivity values were then plotted against half the current electrodes spacing $(\mathrm{AB} / 2)$ on bilogarithmic coordinates. VES curves were interpreted quantitatively by partial curve matching and computer-assisted 1D forward modelling with the WinResist version 1.0 software. Five pits were also dug along the profiles, three on the profile along $\mathrm{E}-\mathrm{W}$ azimuth and two on profiles along $\mathrm{N}-\mathrm{S}$ (Fig. 3) to ground truth the interpreted results. It should be noted that the depth correlation between $2 \mathrm{D}$ pseudosection and borehole data was done at different scales as the scale of the RES2DINV software cannot be adjusted; however, the correlations were carefully done.

\section{Sample collection}

Soil samples were collected from the five pits at intervals of $0.5,1.0,1.5,2.0,2.5$ and $3.0 \mathrm{~m}$ and kept in polythene bags. The pitting was terminated when the water table was reached. Laboratory grain size analysis and permeability test were carried out on each sample.

\section{Laboratory analysis}

\section{Grain size analysis}

The samples were air-dried, and since the samples were friable; disaggregation was done with fingers, while some were done with pestle and mortal. This was followed by sieve analysis using standard laboratory procedure ASTM D 6913 (ASTM 2017). Cumulative curves were plotted from the grain size analysis data, and relevant textural parameters were also deduced.

\section{Hydraulic conductivity determination}

Laboratory determination of hydraulic conductivity was carried out using the constant head permeability test following standard procedure (ASTM D2434-68). The set-up of the permeameter tests was based on the principle of Darcy's experiment which established the relationship between the flux of water through a porous medium and the hydraulic head difference at both ends of the medium.

\section{Results and discussion}

\section{Electrical resistivity survey}

\section{Profile 1}

The inversion model shows four lithological units. The first layer is the topsoil having resistivity values between 38 and $92 \Omega \mathrm{m}$. This layer could be referred to as clayey 
Fig. 3 Location map showing profile lines, VES points, pits and existing borehole

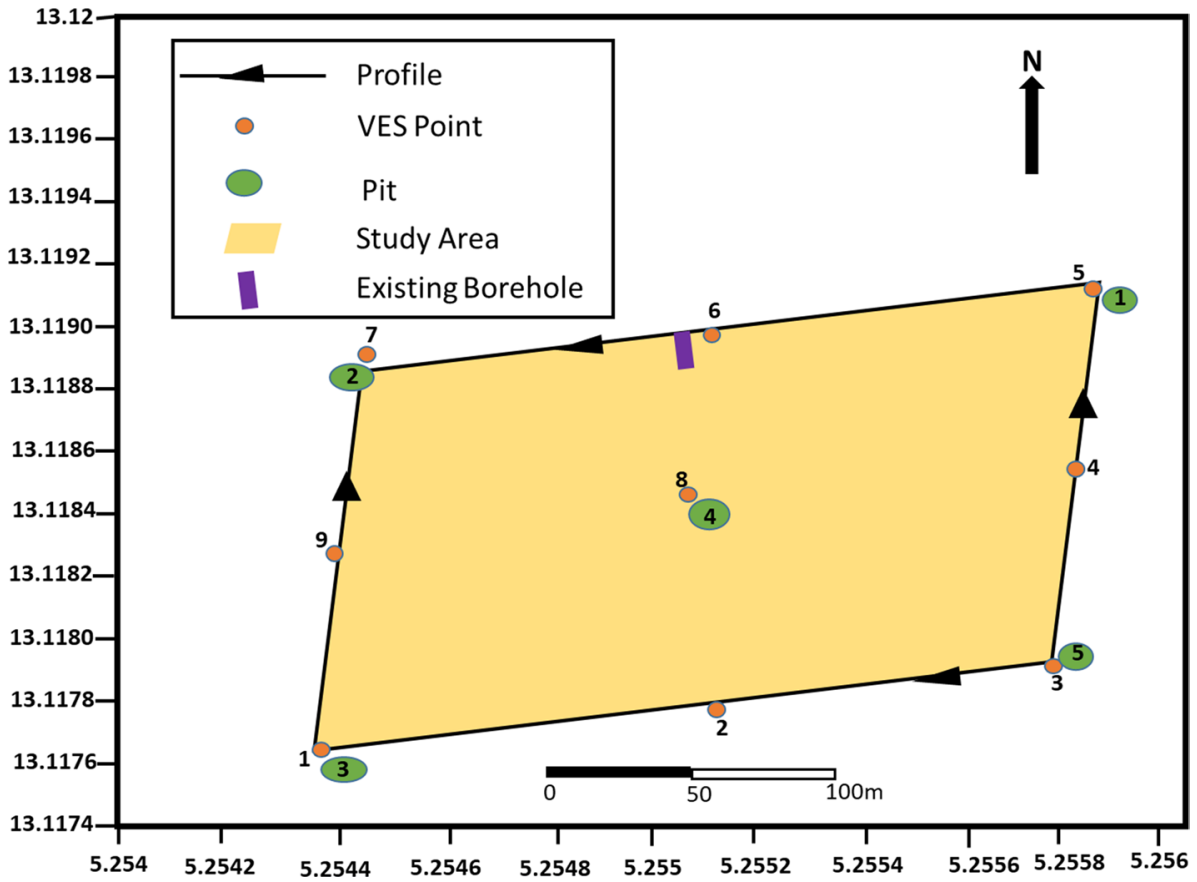

sand due to the resistivity values (Loke 2000). It occurs up to depth of about $2.5 \mathrm{~m}$ and extends to station $130 \mathrm{~m}$. The layer has pockets of clay embedded within it occurring at stations $30-50 \mathrm{~m}$. Next to this layer is a prominent highresistivity zone (224 to $>348 \Omega \mathrm{m}$ ) at a depth of about 2.5 to $17.5 \mathrm{~m}$ (Fig. 4a) which is suggestive of sandy formation. The sand formation layer is believed to be saturated with water because of the resistivity of this layer. Below the high-resistivity zone is a clayey sand with resistivity value between $38 \Omega \mathrm{m}$ and $92 \Omega \mathrm{m}$. The last layer is a low-resistivity (16-38 $\Omega \mathrm{m})$ portion which could be clay formation, because of the extremely low resistivity value (Loke 2000).

The lithological horizon of pit 1 (Fig. 4b) indicates clay with thickness between 0 and $1 \mathrm{~m}$ and fine sand having thickness variation between 1 and $2.5 \mathrm{~m}$. The result of the profile in pit 1 corroborates the geometry of sand bodies observed on the pseudosection.

\section{Profile 2}

The pseudosection in Fig. 5a shows four geoelectric sequences. The first layer is a topsoil with low-resistivity (31-47 $\Omega \mathrm{m})$ zone extending from station 19 to about $135 \mathrm{~m}$ and having a depth of about $2.6 \mathrm{~m}$. The second layer is a considerably high-resistivity (72-> $167 \Omega \mathrm{m})$ zone extending from station 6 to about $142 \mathrm{~m}$ and occurring at a depth of about $15.9 \mathrm{~m}$. This layer could be a sandy formation (Loke 2000) and is suspected to be filled with water because of its resistivity values.

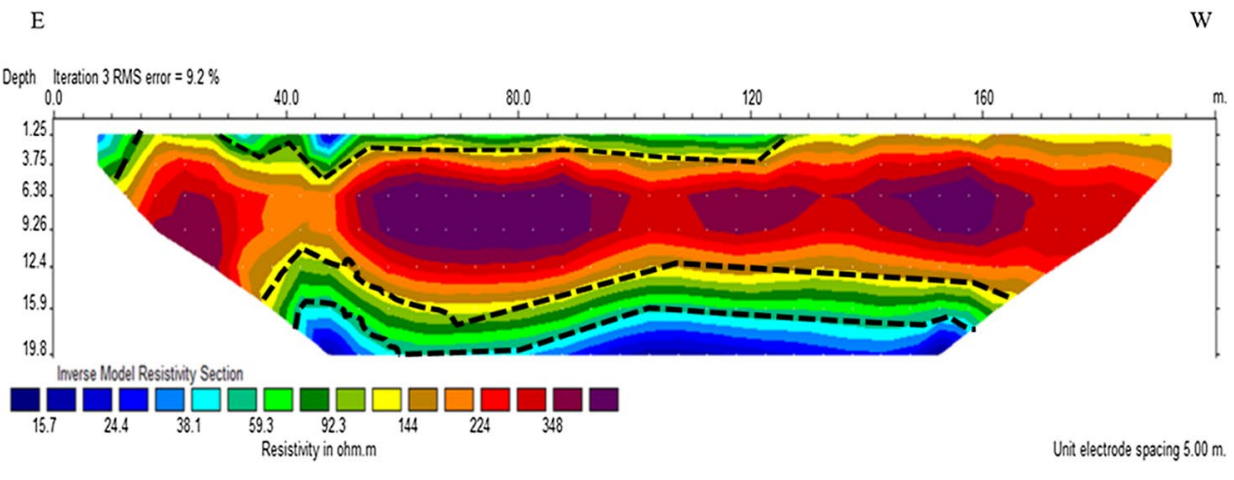

(a)

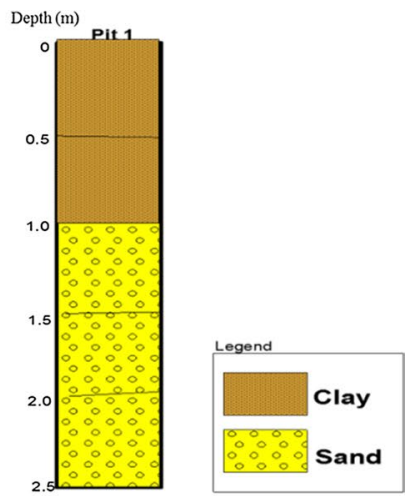

(b)

Fig. 4 Profile 1: a pseudosection of profile 1, $\mathbf{b}$ soil profile in pit 1 
$\mathrm{N}$

Depth Iteration 3 RMS error $=13.1 \%$

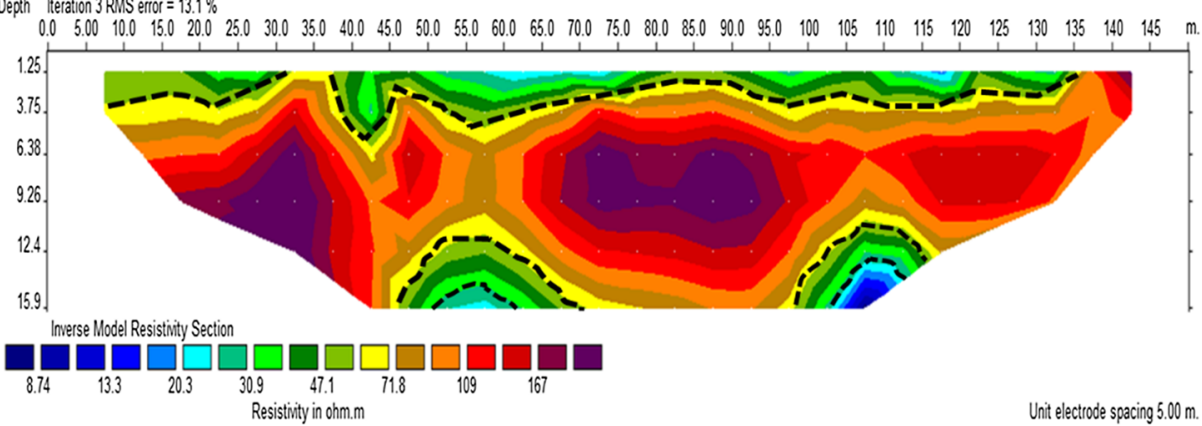

(a)

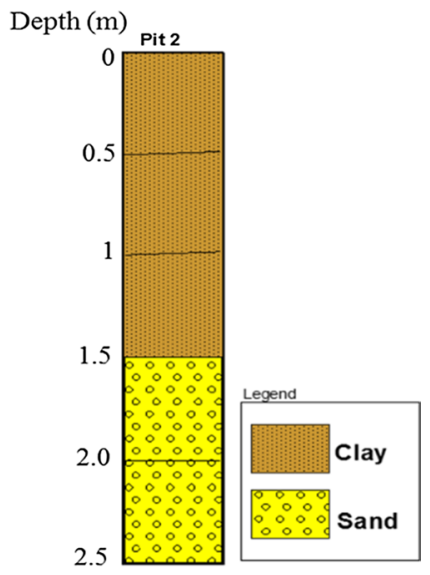

(b)

Fig. 5 Profile 2: a pseudosection of profile 2, $\mathbf{b}$ soil profile in pit 2

Below this layer is clayey sand formation with resistivity value between 31 and $47 \Omega \mathrm{m}$. The fourth layer is a very low-resistivity ( 9 and $13 \Omega \mathrm{m}$ ) zone of clay formation (Loke 2000). The soil profile of pit 2 in Fig. $5 \mathrm{~b}$ also shows clay with thickness between 0 and $1.5 \mathrm{~m}$ and fine sand that occurred between 1.5 and $2.5 \mathrm{~m}$. This agrees with the pseudosection for the characterization of the geometry of floodplain in the area.

\section{Profile 3}

From the pseudosection in Fig. 6, a low-resistivity topsoil was observed extending from station 68 to about $145 \mathrm{~m}$ with a depth of about $2.8 \mathrm{~m}$; also a small low-resistivity portion was seen extending between stations 35 and $45 \mathrm{~m}$ at a depth between 2.7 and $7.1 \mathrm{~m}$. High-resistivity (214-> $644 \Omega \mathrm{m})$ portions were observed at stations $15-35 \mathrm{~m}$ and $45-140 \mathrm{~m}$ at depths between 3.75 and $12.4 \mathrm{~m}$. Below this high-resistivity zone are very low-resistivity portions which could be clay or saturated clay in nature (Loke 2000).

\section{Profile 4}

The pseudosection in Fig. 7 shows a distorted subsurface probably due to the nature of this area. This profile was run on a site that was formerly a river, and therefore, it is expected that several sediments or alluvial sediments had been deposited over a long period of time compared to other profiles. However, the section generally shows three geoelectric sequences. A low-resistivity (3-13 $\Omega \mathrm{m}$ ) topsoil was observed at stations 122 to about $159 \mathrm{~m}$ occurring at a depth of about $2.3 \mathrm{~m}$ and at stations $30-70 \mathrm{~m}$ at a depth of about $9.26 \mathrm{~m}$. This layer could be said to be clay due to the very low resistivity. A high-resistivity (219-> $444 \Omega \mathrm{m})$ layer, believed to be saturated with water, was observed between stations 40 to $50 \mathrm{~m}$ (depth is between 3.75 and $7.1 \mathrm{~m}$ ) and 70 to $95 \mathrm{~m}$ (at depth of $2.7 \mathrm{~m}$ downward). This layer could be sand formation. The third layer has resistivity between 26 and $108 \Omega \mathrm{m}$ which is suggestive of clayey sand formation.
Fig. 6 Pseudosection of profile 3
$\mathrm{N}$ Deph Heration 3 RUS error $=25.4 \%$

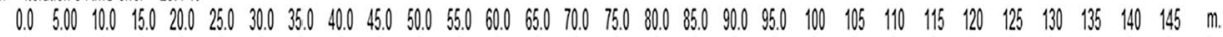

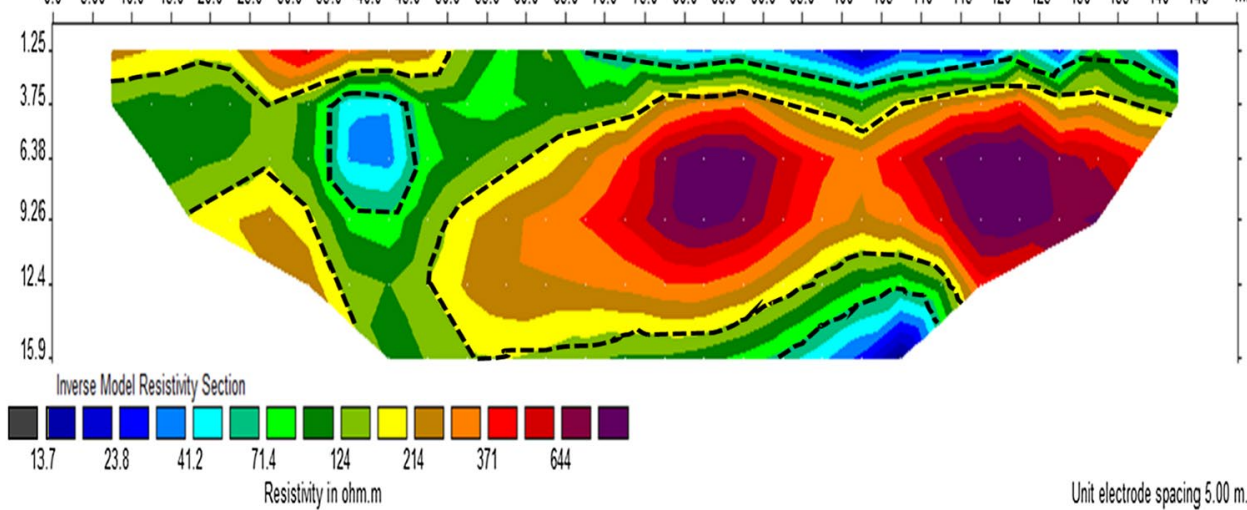


Fig. 7 Pseudosection of profile 4

Fig. 8 VES curves, a K-type, b KH-type
E

Depth lieration 3 RMS error $=32.6 \%$

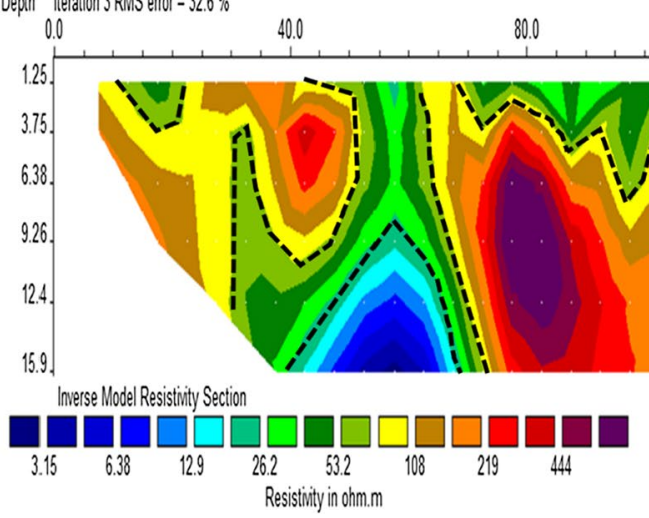
120 160

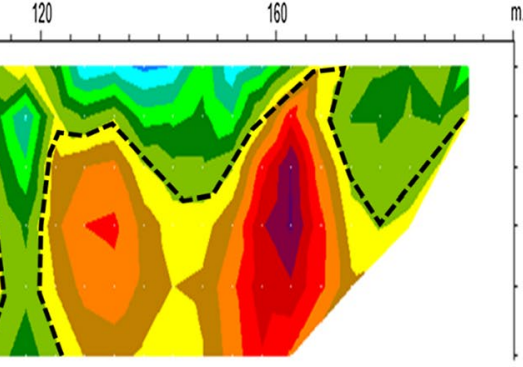

Unit electrode spacing $5.00 \mathrm{~m}$ (a)

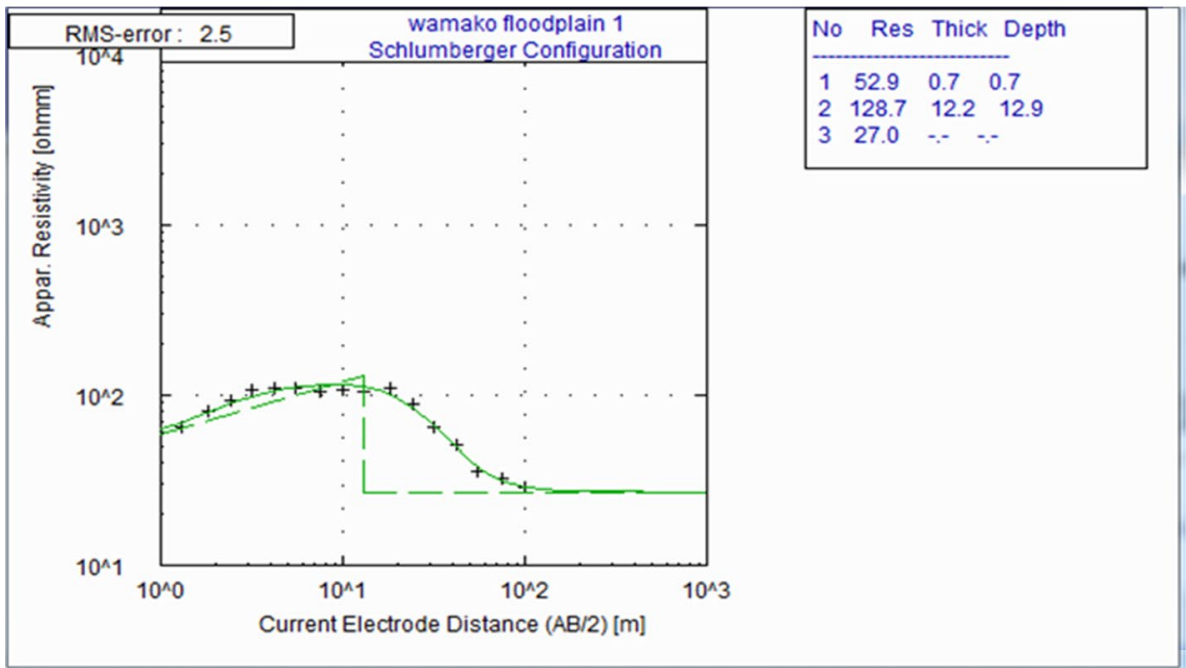

(b)

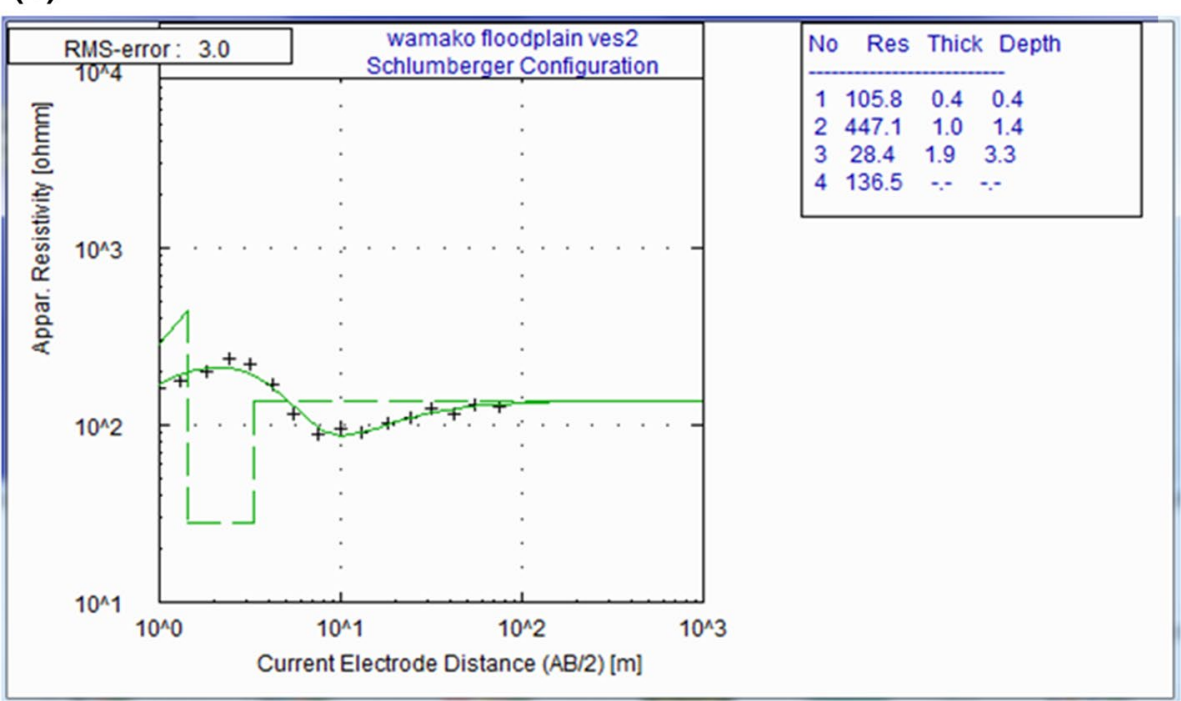




\section{Results of VES}

Typical representatives of the apparent resistivity curves obtained from the study area are shown in Fig. 8 while the results of interpretation of the curves are given in Table 1. The results of VES corroborate those of 2D resistivity imaging in that three layers were delineated which are topsoil, sandy material and clayey/saturated clayey material. The VES results show the resistivity of the first layer (topsoil) varies between 10 and $106 \Omega \mathrm{m}$ having thickness of about $1.8 \mathrm{~m}$, while resistivity value of the second layer ranges between 129 and $447 \Omega \mathrm{m}$ with thickness of about $12 \mathrm{~m}$ which could be sandy material. This layer is believed to be saturated with water because of the resistivity of the layer, and also, the sandy material could be highly porous and highly permeable. The third layer delineated by VES is the clayey/saturated clayey material.

\section{Hydrogeologic properties}

In order to understand the properties of the sandy material that could serve as aquifer in the floodplain, the results of grain size distribution of the study area from different levels in the pits within Wamako floodplain are presented in Fig. 9a, b. As shown in the figure, most of the samples are predominantly within uniform medium sand range, which could indicate that the sands are porous and moderately permeable.

\section{Hydraulic conductivity (K)}

The results of the hydraulic conductivity $(K)$ test are presented in Table 2. The test was carried out to test the permeability of the sands.

The estimated $K$ values range between $7.63 \times 10^{-5}$ and $2.13 \times 10^{-6} \mathrm{~m} / \mathrm{s}$. which fall within a range of $10^{-2}-10^{-6}$
Table 1 Summary of the VES results

\begin{tabular}{|c|c|c|c|c|c|c|}
\hline VES & Layer & $\begin{array}{l}\text { Resistivity } \\
(\Omega \mathrm{m})\end{array}$ & Thickness (m) & Curve type & Probable lithology & $\begin{array}{l}\text { Hydrogeologi- } \\
\text { cal signifi- } \\
\text { cance }\end{array}$ \\
\hline & 1 & 53 & 0.7 & & Topsoil & Poor \\
\hline \multirow[t]{2}{*}{1} & 2 & 129 & 12.2 & & Sandy material & Good \\
\hline & 3 & 27 & - & $\mathrm{K}$ & Clay & Fair \\
\hline \multirow[t]{4}{*}{2} & 1 & 106 & 0.4 & & Topsoil & Poor \\
\hline & 2 & 447 & 1.0 & & Sandy material & Good \\
\hline & 3 & 29 & 1.9 & $\mathrm{KH}$ & Clay & Fair \\
\hline & 4 & 137 & - & & Clay & Fair \\
\hline \multirow[t]{3}{*}{3} & 1 & 13 & 1.3 & & Topsoil & Poor \\
\hline & 2 & 305 & 7.0 & $\mathrm{~K}$ & Sandy material & Good \\
\hline & 3 & 47 & - & & Clay & Fair \\
\hline \multirow[t]{3}{*}{4} & 1 & 23 & 0.9 & & Topsoil & Poor \\
\hline & 2 & 313 & 11.4 & $\mathrm{~K}$ & Sandy material & Good \\
\hline & 3 & 13 & - & & Clay & Fair \\
\hline \multirow[t]{3}{*}{5} & 1 & 42 & 1.1 & & Topsoil & Poor \\
\hline & 2 & 221 & 7.5 & $\mathrm{~K}$ & Sandy material & Good \\
\hline & 3 & 38 & - & & Clay & Fair \\
\hline \multirow[t]{3}{*}{6} & 1 & 10 & 0.7 & & Topsoil & Poor \\
\hline & 2 & 332 & 12.2 & $\mathrm{~K}$ & Sandy material & Good \\
\hline & 3 & 30 & - & & Clay & Fail \\
\hline \multirow[t]{3}{*}{7} & 1 & 12 & 1.5 & & Topsoil & Poor \\
\hline & 2 & 271 & 11.4 & K & Sandy material & Good \\
\hline & 3 & 25 & - & & Clay & Fair \\
\hline \multirow[t]{4}{*}{8} & 1 & 51 & 0.5 & & Topsoil & Poor \\
\hline & 2 & 187 & 1.2 & KH & Sandy material & Good \\
\hline & 3 & 51 & 4.2 & & Clay & Fair \\
\hline & 4 & 235 & - & & Clay & Fair \\
\hline \multirow[t]{3}{*}{9} & 1 & 33 & 0.6 & & Topsoil & Poor \\
\hline & 2 & 317 & 3.3 & $\mathrm{~K}$ & Sandy material & Good \\
\hline & 3 & 53 & - & & Clay & Fair \\
\hline
\end{tabular}



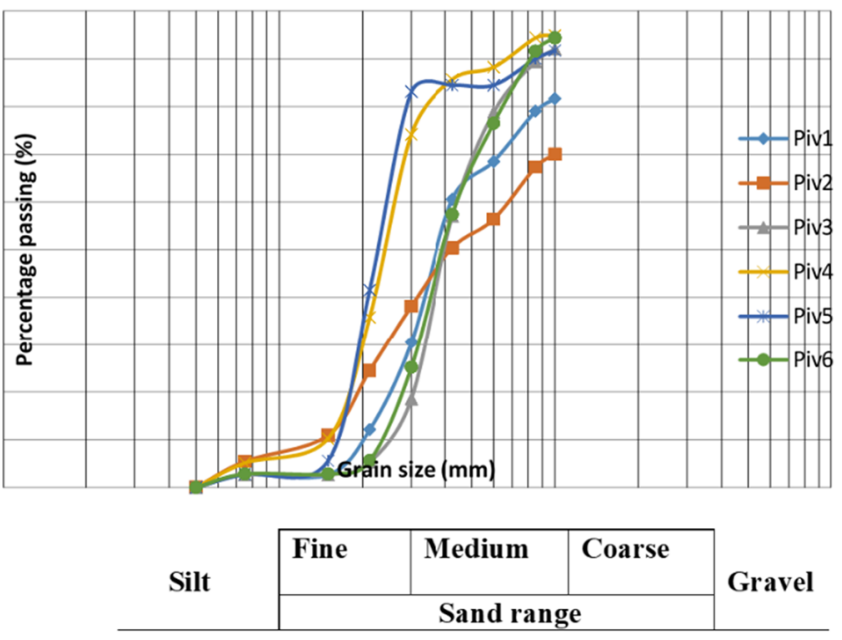

(a)
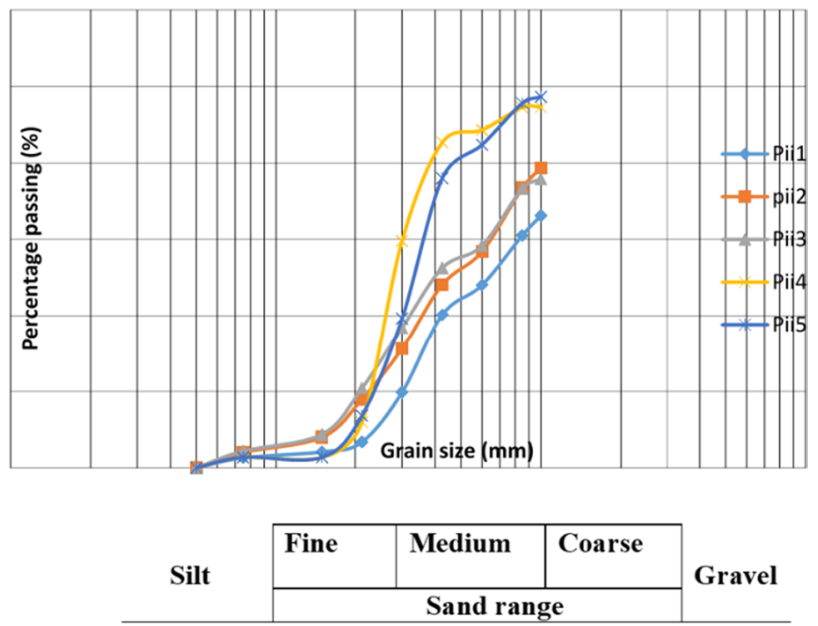

(b)

Fig. 9 Representative grain size distribution curves of the Wamako area, a pit 1, b pit 4

Table 2 Hydraulic conductivity $(\mathrm{m} / \mathrm{s})$

mer the samples. This was interpreted to be clean sand which is moderately to highly permeable (Freeze and Cherry 1979).

\begin{tabular}{ll}
\hline Pit & $K$ \\
\hline Pi1 & 0.0000455 \\
Pi2 & 0.00000345 \\
pi3 & 0.00000345 \\
Pi4 & 0.0000327 \\
Pi5 & 0.0002353 \\
Pii1 & 0.0000763 \\
Pii2 & 0.00000653 \\
Pii3 & 0.00000543 \\
pii4 & 0.0000132 \\
Pii5 & 0.0000032 \\
Piii1 & 0.0000631 \\
Piii2 & 0.00000342 \\
Piii3 & 0.0000232 \\
Piii4 & 0.0000212 \\
Piii5 & 0.0000823 \\
Piii6 & 0.00000321 \\
Piv1 & 0.0000321 \\
Piv2 & 0.0000478 \\
Piv3 & 0.0000213 \\
piv4 & 0.00000431 \\
Piv5 & 0.00000531 \\
Piv6 & 0.0000213 \\
Pv1 & 0.0000521 \\
Pv2 & 0.0000332 \\
Pv3 & 0.0000218 \\
Pv4 & 0.00000214 \\
Pv5 & 0.00000317 \\
\hline & \\
&
\end{tabular}

\section{Conclusions}

The geophysical investigation involving electrical resistivity method has been used to understand the internal geometry and heterogeneity of the floodplain aquifer system. From the VES and 2D resistivity interpretations, three to four subsurface layers were delineated: the topsoil, sandy material and clayey materials. The VES results show the resistivity of the first layer (topsoil) varies between 10 and $106 \Omega \mathrm{m}$ with thickness of about $1.8 \mathrm{~m}$, while resistivity value of the second layer ranges between 129 and $447 \Omega$ m with thickness of about $12 \mathrm{~m}$ which could be sandy material. This layer is believed to be saturated with water because of the resistivity of the layer, and also, the sandy material could be highly porous and highly permeable. This layer was further confirmed by pitting around the study area. The pitting was abruptly stopped because the water table is very close to the surface $(2.5-3.0 \mathrm{~m})$, and this indicates that the aquifer is within the sandy material. The third and fourth layers are believed to be clay/saturated clayey materials having resistivity values ranging from 13 to $53 \Omega \mathrm{m}$. Also the hydraulic test revealed that the sandy material is highly permeable and this allows high movability and supply of groundwater within the floodplain. Hydrogeologically, the topsoil is not important because the degree of water saturation in this layer is very low and cannot be utilized for groundwater. The second layer is relevant in the groundwater prospecting, especially because it is thick enough and the amount of water saturating is high, and also it could serve as a major component of the aquifer in the study area. Based on the result of this investigation, the development of groundwater in the study area is feasible. This is expected to support large-scale farming which floodplain in the study area is mostly used for.

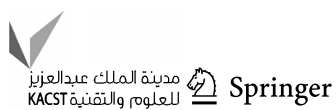


Open Access This article is distributed under the terms of the Creative Commons Attribution 4.0 International License (http://creativeco mmons.org/licenses/by/4.0/), which permits unrestricted use, distribution, and reproduction in any medium, provided you give appropriate credit to the original author(s) and the source, provide a link to the Creative Commons license, and indicate if changes were made.

\section{References}

Adabanija MA, Oladunjoye MA (2014) Investigating internal geometry of a flood plain in basement complex terrain of south-western Nigeria using electrical resistance tomography. Int J Multidiscip Curr Res 2:925-931

Adeeko TO, Samson DO (2018) Application of electrical resistivity in mapping subsurface characteristics. Asian J Environ Ecol $6(2): 1-12$

Adelana M, Olasehinde PI, Vrbka P (2002) Groundwater recharge in the Cretaceous and Tertiary sediment aquifers of northwestern Nigeria using hydrochemical and isotopic techniques. In: Bocanaegra E, Matinez D, Massone $\mathrm{H}$ (eds) Groundwater and human development, Mar de Plata, Argentina, pp 49-72

Alagna V, Bagarello V, Di Prima S, Iovino M (2015) Determining hydraulic properties of a loam soil by alternative infiltrometer techniques. Hydrol Process. https://doi.org/10.1002/hyp.10607

Altunkaynak A (2007) Steady-state groundwater flow model with variable hydraulic conductivity. Hydrol Sci J 52(1):221-229

Anyadike R (1983) Seasonal and annual rainfall variations over Sudan. Int J Climatol 13:567-580

ASTM D2434-68(2000) (2000) Standard test method for permeability of granular soils (constant head). ASTM International, West Conshohocken. www.astm.org

ASTM D6913/D6913M-17 (2017) Standard test methods for particle-size distribution (gradation) of soils using sieve analysis. ASTM International, West Conshohocken. www.astm.org

Bassey C, Eminue O (2014) Preliminary evaluation of major and trace elements content of Cretaceous-Palaeogene Formations of the Sokoto Basin, northwestern Nigeria. NAFTA 65(1):69-76

Bouwer H (1989) The Bouwer and Rice slug-test-an update. Ground Water 27(3):304-309

Butler JJ, Zhan X (2004) Hydraulic tests in highly permeable aquifers. Water Resour Res 40:12. https://doi.org/10.1029/2003W R002998

Das NN, Mohanty BP, Efendiev Y (2010) Characterization of effective saturated hydraulic conductivity in an agricultural field using Karhunen-Loeve expansion with the Markov chain Monte Carlo technique. Water Resour Res 46:W06521

Ette OJ, Okuolfu CA, Adie DA, Igboro SB, Alagbe SA, Etteh CC (2017) Application of environmental isotopes to assess the renewability of groundwater of continental intercalaire aquifer of Sokoto Basin in northwestern Nigeria. Groundw Sustain Dev 4:35-41

Fallico C (2014) Reconsideration at field scale of the relationship between hydraulic conductivity and porosity: the case of a sandy aquifer in South Italy. Sci World J. https://doi. org/10.1155/2014/537387

Freeze RA, Cherry JA (1979) Groundwater. Prentice-Hall Inc., Englewood Cliffs, New Jersey, pp 26-70

Hamidu H, Lawal M, Abdulganiyu Y, Kwaya MY, Grema HM, Ibrahim HA, Kitha M, Yelwa NA (2017) Re-evaluation of shallow floodplain aquifers groundwater potentials and storage of Sokoto basin, northwestern Nigeria. Am J Water Res 5(3):72-84. https:// doi.org/10.12691/ajwr-5-3-3
Hess T, Steephene W, Marya U (1995) Rainfall trends in the Northeastern arid zone of Sudan. Agric For Meteorol 74:87-97

Hogan JM, Kamp GV, Barbour SL, Schmidt R (2006) Field methods for measuring hydraulic properties of peat deposits. Hydrol Process 20:3635-3649. https://doi.org/10.1002/hyp.6379

Kogbe CA (1976) Outline of the geology of the Iullemmeden Basin in northwestern Nigeria. In: Kogbe CA (ed) Geology of Nigeria, Elizabethan Publ. Co., Lagos, pp 331-338

Kogbe CA (1979) Geology of the southwestern (Sokoto) sector of the Iullemmeden Basin. Bull Dep Geol 2(1):420

Loke MH (2000) Electrical imaging surveys for environmental and engineering studies. Geometrics, New York

Loke MH, Chamber JE, Rucker DF, Kuras O, Wilkinson PB (2013) Recent developments in the direct-current geoelectrical imaging method. J Appl Geophys 95:135-156

Mostafa M, Radwan A (2017) Application of electrical resistivity measurement as quality control test for calcareous soil. HBRC J. https://doi.org/10.1016/j.hbrcj.2017.07.001

Nigeria Geological Survey Agency (NGSA) (2004) Geological and mineral resources map of Sokoto State. Published by the authority of the Federal Republic of Nigeria

Olaojo AA, Oladunjoye MA, Sanuade OA (2018) Geoelectrical assessment of polluted zone by sewage effluent in University of Ibadan Campus Southwestern Nigeria. Environ Monit Assess 190:24. https://doi.org/10.1007/s10661-017-6389-1

Olaseeni OG, Sanuade OA, Adebayo SS, Oladapo MI (2018) Integrated geoelectric and hydrochemical assessment of Ilokun dumpsite, Ado Ekiti, southwestern Nigeria. Kuwait J Sci 45(4):82-92

Oyeyemi KD, Aizebeokhai AP, Olofinnade OM, Sanuade OA (2018) Geoelectrical investigations for groundwater exploration in crystalline basement terrain, SW Nigeria: implications for groundwater resources sustainability. Int J Civil Eng Technol 9(6):765-772

Revil A, Karaoulis M, Johnson T, Kemma A (2012) Review: some low-frequency electrical methods for subsurface characterization and monitoring in hydrogeology. Hydrol J 20:617-658

Reyment RA (1965) Aspect of geology Nigeria. Ibadan University Press, Ibadan

Riwayat AI, Nazri MAA, Abidin MHZ (2018) Application of electrical resistivity method (ERM) in groundwater exploration. J Phys: Conf Ser 995:012094

Sanuade OA, Olaojo AA, Akanji AO, Oladunjoye MA, Omolaiye GE (2017) A resistivity survey of phosphate nodules in Oshoshun, Southwestern Nigeria. RMZ Mater Geoenviron 65(2):103-114. https://doi.org/10.1515/rmzmag-2018-0006

Siltecho S, Hammecker C, Sriboonlue V, Clermont-Dauphin Trelo-ges V, Antonio ACD, Angulo-Jaramillo R (2015) Use of field and laboratory methods for estimating unsaturated hydraulic properties under different land uses. Hydrol Earth Syst Sci 19:1193-1207

Sobotkova M, Snehota M, Dohnal M, Ray C (2011) Determination of hydraulic properties of a tropical soil of Hawaii using column experiments and inverse modeling. Rev Bras Cienc Solo 35:1229-1239

Stan D, Stan-Kleczek I (2014) Application of electrical resistivity tomography to map lithological differences and subsurface structures (Eastern Sudetes, Czech Republic). Geomorphology 221:113-123

Publisher's Note Springer Nature remains neutral with regard to jurisdictional claims in published maps and institutional affiliations. 